\title{
The Practice of Postmodern Musical Culture in Chinese Vocal Music
}

\author{
Tao Liu \\ Xiamen University, Xiamen, Fujian, China, 361005
}

Keywords: Postmodernism, Pluralistic music culture, Vocal music art

\begin{abstract}
In the 1960s, the postmodernist trend of thought that originated in Europe and the United States has become a cultural feature of modern society globally. As its theoretical essence lies in the understanding and tolerance of multicultural values on culture and life, it has promoted economic and cultural growth, development and innovation. The development of vocal music in contemporary China has shown its outstanding features in the current era of pluralism. This paper analyzes the "multiculturalism" which is one of the main characteristics of postmodernism and takes the development of Chinese vocal music as the main line, examines and studies the influence of the postmodernism on contemporary Chinese vocal music ideas and practices. At the same time, it also explores the profound influence of social thoughts such as the protection of intangible cultural heritage and the development of cultural industries on the concept and practice of vocal music in China and its development.
\end{abstract}

\section{Introduction}

Postmodern cultural view occupies an important position in postmodernist ideology, and postmodern musical cultural view is also an integral part of post-modern cultural view. In the case of a social group or ethnic group, their behavior is often influenced and influenced by the prevailing ideas and ideological trends prevailing over a certain period of time. Therefore, in my opinion, the development of present vocal performance art in our country is directly affected by western postmodern musical culture, the trend of cultural heritage protection and the craze of cultural industry.

\section{Postmodernist Musical Culture and Contemporary Chinese Vocal Performing Arts}

Composers in the postmodern period underwent great changes in the concept of music. Mainly as follows: 1, in each of the works, strive to achieve the novel and unique thinking; 2, pay attention to each work embodied in the concept of generation and generation process; 3 , with a calm and objective attitude to re-examine include Modern music itself, and to absorb pop music and non-Western music culture in a more positive manner.

This attitude makes music expression more diversified, because postmodernism has a progressive "rebel consciousness" and it bravely criticizes and denies the old things. In terms of music and culture, the artists show extraordinary courage and bold experiments in innovation to criticize and deny traditional culture. Electronic music, incidental music, concrete music, dangerous music, biological music, natural music and so forth accompanying the high-tech and electronic means of post-industrial society are the concrete manifestation of these innovative experiments.

Viewing the contemporary Chinese vocal performance art from a postmodern perspective, this thinking of "rebellious consciousness and subversion of tradition" provides more possibilities and more space for the diversified development of vocal performances. From the perspective of singing skills, the concept of post-modern music culture has promoted the innovation of forms of vocal performances. On the basis of the three most popular singing styles of beauty, nation, and pop, new forms such as Minmetals, singing classification, different singing methods grafting each other melt, but also produce a new vocal singing methods and techniques. In the form of expression, the vocal performance is not only a show of singing skills, or a simple voice show, it focuses more on the performer's body language and the audience's scene interaction. In the music element, the creation 
of vocal works begins to diversify towards hearing. Especially in popular vocals, composers often incorporate elements of traditional Chinese music. For example, Liu Huan plays the ending song for the drama "Hu Xueyan" And "grudges," the perfect combination of Chinese pop music and traditional opera elements to create a refreshing style.

The concept of post-modern music culture is not only deviant and questioning, but also dependent and interdependent on the traditional concept of music and culture. We know that the generation of any new things is based on the old things, and the postmodern music of China On the one hand, it betrays the traditional Chinese cultural concept of unity (Chinese singing style or Chinese modern vocal music system), dual cultural concept (folk singing style and college foreign singing style), and on the other hand, based on China's In the traditional culture, the development and diversification of the styles and styles of postmodern vocal performing arts, such as the concept of ternary culture (nationality, beauty and popularity) and the new so-called "Minmetals, Meintone, The public through "and so a variety of new singing method. Coupled with the input of foreign cultures, the advent of the era of globalization and the constant innovation of modern scientific and technological means, it is foreseeable that the method of singing in China in the future will go beyond the existing ones.

On the one hand, if performers can properly understand the meaning of post-modernism and actively use it for pioneering and innovating, and constantly creating new vocal music singing style and system, it not only can give listeners various aural sensations, but also cause different listeners' minds Resonance, so that people achieve physical and mental pleasure. At the same time, it also embodies the policy of "letting all flowers bloom and all schools contend". Only in this way can we achieve the great prosperity and great development of our music culture and vocal music art and meet the ever-growing spiritual and cultural needs of the general public. On the other hand, if performers isolate the concept of postmodernity and paranoidly as pursuing novelty, excitement and distinctiveness, it is very likely that other adverse consequences will arise. Regardless of the singer singing skills regardless of the quality of cultural accomplishments, determines the performance of its performance on the stage, the deliberate pursuit of novelty and excitement, different, often result in abandoning the bottom, the opposite effect. Especially in pop music, many vocal singers hope to be presented to the audience through non-mainstream forms of expression such as extreme individuality, such as fancy dress and dress, grotesque movements and gestures. So deliberately expressed misunderstood postmodern artistic ideal, combined with the traditional Chinese culture and national aesthetic habits do not understand the historical development of various forms of music, creative process, creative ways do not understand, more easily distorted the form of postmodern music the expression, let alone a valuable cultural innovation.

\section{The Protection of Cultural Heritage Birth "Diversified" Vocal Singing}

As a multi-ethnic country with a long history and profound cultural heritage, China's cultural heritage contains the unique spiritual values, modes of thinking and imagination of the Chinese nation, embodies the vitality and creativity of the Chinese nation and is the crystallization of the wisdom of all ethnic groups. The treasure of all human civilization. Folk music in China is a treasure trove of resources. Singing methods and forms of national songs are an important part of music and cultural heritage. For example, Humahu and Ningxia Flowers in Inner Mongolia all reflect the unique cultural characteristics and diversity of ethnic groups Style, style of singing is also immediately born.

In order to implement the 16th National Congress of the Communist Party of China on "supporting the protection of important cultural heritages and excellent folk art" and fulfilling our country's obligation to accede to the "Convention for the Safeguarding of the Intangible Cultural Heritage" of UNESCO, the State Council has promulgated the "Opinions on the protection of material and cultural heritage. " Through the protection of non-material cultural heritage and the inheritance and development of outstanding traditional ethnic cultures, the pride, confidence and cohesion of the Chinese nation will be greatly enhanced, the cultural quality of the entire nation will be enhanced, the healthy cultural ecology will be protected, and the social and economic 
development of our country and culture and other undertakings play a full, coordinated and sustainable development play a major role. Through the protection of non-material cultural heritage, it is of great significance to the promotion and cultivation of the national spirit, the enhancement of national unity and safeguarding the stability and unity of the country and the encouragement of people of all ethnic groups in building a prosperous, democratic and civilized great nation.

As China officially started the work on strengthening the protection of intangible cultural heritage in our country, more and more people began to pay attention to Chinese folk music. The most typical example is the "original" (let's call this appellation appropriate) into the television media, folk songs, as an important part of the mainstream media, has become more and more the focus of attention, but also evoke the folk music The development of "original ecology" folk songs that love and inherit protection awareness and protect the characteristics of various nationalities in our country also permanently preserve the value of our intangible cultural heritage. "Original ecology" folk songs have become an important content in the television media. Many programs with original music and cultural elements have appeared in the programs of CCTV and provincial and municipal TV stations. Some of these sections also feature "original" folk songs as the main content, such as CCTV's "Folk song • China" section, "Charm12" column; Inner Mongolia TV's "Music Tribes" section, Guangxi Satellite TV's "Singing Mountain Songs" section of Shanghai Satellite TV's "Sea Echo" section and so on.

On May 18, 2001, UNESCO announced the first batch of "Representatives of Human Population and Intangible Heritage" in Paris, for a total of 19 items, the vast majority being folk tradition ceremonies declared by developing countries, spoken language and performing arts projects, China declared "Kunqu opera" is also on the list. Since China officially launched the "Project of Saving and Protecting the Chinese Oral and Intangible Heritage" in 2002, governments and masses at all levels have shown unprecedented enthusiasm for this great project and have achieved remarkable results in their practical work: Kunqu Opera, Guqin, Uygur Muqam, Uyud Tingdu (Mongolian traditional long-tune), Fujian Nanyin have been approved by UNESCO as "the representative works of human oral and intangible heritage"; China's first batch of intangible cultural heritage and national directory The publication of the list of recommended names; and the State Council has decided that the second Saturday in June of each year from June 2006 shall be China's "Cultural Heritage Day."

Both the state's policy support and the establishment of the "original" folk song television program provide a platform for our "pluralistic" vocal singing style to provide a platform for meeting the public's "diversified" aesthetic needs. The protection of cultural heritage provides a resource guarantee. The differences and pluralism emphasized by postmodern music culture conforms to the requirements of protecting the musical cultural heritage of all ethnic groups and should be one of the sources of theoretical support for the existence of "diversified" vocal music singing.

\section{The Development of Cultural Industries Calls for "Diversified" Vocal Singing Innovation}

Culture Industry, also translated as cultural industry, is a central concept of expressing the cultural crisis of late capitalism. It is also a general term for mass culture of Western Marxist Frankfurt School. This concept expression is an extreme direction of capitalist culture, that is to say fully to the general public. In the book "Enlightenment Dialectics" by Horkheimer and Adorno, the theory of cultural industry was fully and deeply discussed. The Dialectics of Enlightenment was written during the Second World War and published after the war with an object of discourse on European culture in the first half of the twentieth century. Horkheimer and Adorno argue that "the products of the cultural industry are used everywhere, and can be consumed flexibly, even in the amusement and recreational situation, but every product of the cultural industry is economically great machine A specimen, all from the beginning, at work, at rest, as long as he breathe, he can not do without these products."

The emergence of post-modernism is a great change in the world today. There has been such a new paradigm of equal dialogue, respect for diversity and respect for differences. This is also the 
appeal of culture in the changing of things in the world because the diversity of cultures is the basic characteristic of human society and an important impetus to the progress of human civilization. Music is also a kind of culture. Therefore, the inheritance and development of music need to follow the construction of a new civilization, listen to a variety of voices and carry out diversified dialogues. The concept of postmodernity involves a pluralistic musical culture. The biggest difference between modernity and post-modernity is that the modern world sees the world as a universal and absolutely fundamental concept, and the postmodern world basically views it from the perspective of diversity and diversity. Now music plus s has become an internationally acclaimed method, musics. Postmodern music development includes:

First, music and hearing post-modernization. Take Tan Dun, his music is a kind of postmodern music, is the embodiment of the diversity of human cultural life. Tan shield insist what sound can be music, noise can also be music, which put the absolute standard of the original break. In a sense, his music is deconstructed and uses postmodern collage methods. He reintegrated music elements such as movies, folk songs and modern orchestral music to broaden the scope of sound and music concepts. Tan Dun's music contains a lot of information, all traveling along the postmodern road opened by the West. Western music in the seven or eighties of the last century appeared in Tan Dun's music. For example, the voice of Cannes post office workers can be music some tribes turn the sounds of birds into music. In Africa, they can also turn the sound of the table into a kind of rhythmic music for children to fall asleep slowly. Tan Dun's music enjoys a good reputation in the world, and post-modern music and cultural thoughts have greatly expanded his music audience. His works also have a great marketing space in the international music market.

Second, the postmodernization of musical emotion. In the popular Chinese music scene, Cui Jian and his rock music have their post-modernism significance. Whether in concept or in form, Cui Jian's work is an important representative of Chinese rock music. In essence, rock and roll absolute pursuit of the real life, it abandoned all the fiction of romanticism, giving a strong shock, feeling and participation. Ivan Hewett has said that postmodern music systems are intended to be universal, but the actual audio is often very personal and localized. Cui Jian directly touches people's paralyzed nerves. His croaking and powerful cry seems to arouse the most primordial, life-seeking spirituality of humankind that has long been hated and indifferent to post-industrial society. Cui Jian's works express the true feeling of life in the society of the rapidly changing values in a sensual way directly and enrich the rich connotation of history and the times. His work is a real spiritual talk, it is the most ruthless anatomy of life, but it is the most real. Cui Jian is also known as the father of Chinese rock, his record sales so many singers catch up. It can be seen, this form of postmodern music has a great spiritual and cultural needs and marketing space.

In my opinion, the diversity of vocal singing is the product of the combination of musical hearing and postmodernization of emotions. For example, it is a combination of vocal singing and popular singing. In fact, it draws on Chinese tradition National singing law is a mere advantage. Because the vocals singing method is very scientific, it allows the singer to learn to scientifically sound and make singing easier, so as to better control various forms of songs. This kind of postmodern thinking urges people to innovate vocal singing methods and form more diversified forms of music expression. Different singing styles and different timbres also cultivate different music market spaces to meet the hearing needs of different audiences, but also contributed to the record, radio, television and other media communications industry's prosperity.

\section{Conclusions}

The emergence of postmodernism has had a major impact on all aspects of society. It breaks the modernity's human-centered subjectivity. Its essence is an intellectual anti-rationalism, moral cynicism and perceptual happiness Doctrine in the West, from the "modern" to the "post-modern", it first takes place in the field of practice, and then the corresponding concepts and theories emerge, and then the two develop in interaction. The political, economic, scientific, cultural, to show this, especially in terms of culture and art, and as Baer said in his book Capitalist Cultural Contradictions: (1) Postmodernism is not a new cultural logic, but "pushing the logic of modernism to the extreme ". 
(2) Postmodernism has achieved cultural autonomy in art, which means that culture and art should go beyond universality and emphasize individuality. (3) Postmodernism opposes the proof of aesthetics on life.

The music in the logic of postmodernism went beyond the limitations of the history of Western professional music started in the Middle Ages. People began to attach importance to the folk, ethnic and secular music culture in China. They broke the sacredness, smashing idols, and paid attention to small figures. They broke through the pattern of music the traditional paradigm and the shackles of the modern paradigm to create two new styles of deconstruction and pluralism. As early as 2002, young scholar Zhou Xianbao proposed: "The publication of the ethnographic, musical and musical publishing in various parts of China has formed the objective reality of the diverse coexistence of music cultures of various ethnic groups." Should "recognize the diversity of musical cultures and the different musical cultures "In China's vocal performance, postmodernism has spawned the collision and innovation of vocal, ethnic, popular, and even the people of the United States, the United States, the Chinacomcommunity, and the original singing style of singing, etc. These different styles and types of singing methods, which have become objective facts, deserve the attention of academics and allow them to engage in dialogue on an equal footing.

Mr. Tian Qing, a musicologist in our country, once pointed out: "In our vocal field, there are only three kinds of singing before the" original ecology "- popular, beautiful voice and nationality, and I once compared them respectively to the" style, "Pop is the" wind "is the style of the city." The Book of Songs "in the" wind "are the author of the year's folk people, eighty percent sing love, sing the feelings of individual life.Popular music is also a folk people, Young people sing, all popular songs are the sincere feelings of the individual life in the face of society .Some is the "elegant", intellectual minority art .Singer singing is the song, the main singing party, the motherland, the Yellow River, mother, Father, comrades-in-arms ... expressing a collective, social feeling rather than an individual's "affection." Sadly, most ethnic singing today lacks the individual life experience and is easily vague, repetitive, pale, False, so in this case, 'original' into the mainstream media, which is good. "The concept of postmodern music so that these originally independent singing merge with each other Prompting them to blend, so that more diverse singing style. The postmodern cultural view also influences the expression of different subjects and contents of different singing styles. Different musical expressions with different artistic skills tend to be more fascinating, causing the audience's soul resonance and aesthetic enjoyment.

The influence of the postmodernist view of culture on the art of vocal music has indirectly led to a diversified trend in the development of the record industry and media industry in the cultural industry. This requires that composers and singers continuously work on styles, singing skills, etc. innovation. Not only that, but also this diversified concept has promoted our country's awareness and efforts on the protection of intangible cultural heritage, especially the musical heritage, such as the musical styles and singing methods in such musical heritage as Kunqu Opera, Beijing Opera and Fujian Nanyin. Very worthy of reference and reference. The protection and inheritance of the diversity of folk music culture and the formation and arrival of diversified movements of various nationalities in all the worlds are precisely under the influence of post-modern music and cultural thoughts.

\section{References}

[1] Shen Xuan et al. Western music history compendium [M]. Shanghai. Shanghai Music Publishing House. 2007. 468-469.

[2] Qin Zhigang. Strive to build a total spiritual home of the Chinese nation [N]. China Art. 2008-04-04.

[3] Fan Zuyin. Some Considerations on the Protection of Intangible Cultural Heritage [J]. Music Research. 2006 (1): 10-13.

[4] Max Horkheimer, Theodore Adorno. Dialectics of Enlightenment [M]. Chongqing. Chongqing 
Press. 1990. 118.

[5] Guan Jianhua. Postmodern music education [M]. Xi'an. Shaanxi Normal University Press. 2006. 218.

[6] Ivan Hewett. Repair cracks: the modern crisis of music and post-modern conditions [M]. Sun Hongjie translation. Shanghai. East China Normal University Press. 2006. 92.

[7] Wang Xiao. Cultural Characteristics of Postmodern Music [J]. Huang Zhong. 1999 (4): 30-34.

[8] Song Jin. Western Music - From Modern to Postmodernity [M]. Shanghai Conservatory of Music Press. 2004. 1.

[9] Yin Guojun. Scream of the city - the picture of post-modern architecture [M]. Southwest Normal University Press. 2008. 1-2.

[10] Zhou Xianbao. Western Ethnomusicology and Chinese Music Research [J]. Chinese Music Studies. 2002 (4): 12-17.

[11] Tian Qing. Social Responsibility of a Musicologist [J]. Chinese Musicology. 2011 (4): 5-9. 